\title{
Conceptual Model of Governance Based on John Rogers Commons' Intellectual System
}

\author{
Ahmadreza Roshan ${ }^{1}$ \\ Mahmoud Motevaseli ${ }^{2}$
}

| roshan1390@ut.ac.ir
| motvasel@ut.ac.ir

\begin{abstract}
The main purpose of this paper is to explore the conceptual framework of governance based on the institutional economic approach emphasizing the views of John Rogers Commons. To this end, as a qualitative approach, the focus group of the research method was applied. According to Commons, we first encounter a conflict of interest between individuals, groups, and organizations, which is itself due to the scarcity of resources. Then, collective action is formed to overcome such contradictions. In view of that, there is negotiation, exchange, and collective bargaining that ultimately lead to working rules among human beings to come to a practical result as to live and work together under an agreement that engenders order, security, and dignity. Commons considers working rules as a major means for organizing society's affairs; however, such working rules are formed and developed within the framework of collective democracy. Order and rules cannot be enforced and sustained unless the views and the voice of all parties and stakeholders are heard on an equal basis. Collective democracy as a method of governance facilitates the achievement of such a goal.
\end{abstract}

Keywords: Governance, Institutional Economics, Collective Action, Working Rules, Collective Democracy, John Rogers Commons.

JEL Classification: G38, H10, J58.

\footnotetext{
1. Faculty Member, Institute for Research and Planning in Higher Education (IRPHE), Tehran, Iran (Corresponding Authors).

2. Professor in Economics, University of Tehran, Tehran, Iran.
} 


\section{مدل مفهومى حكمرانى مبتنى بر منظومه فكرى جان راجرز كامونز}

roshan1390@ut.ac.ir

motvasel@ut.ac.ir
احمدرضا روشن

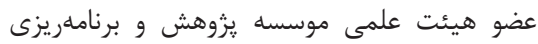

آموزش عالى (نويسنده مسئول).

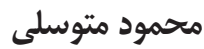

استاد اقتصاد دانشعاه تهران.

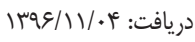

جكيده: هدف اصلى اين يثرهش، يافتن خارجوب مفهومى حكمرانى بر اساس رويكرد اقتصاد

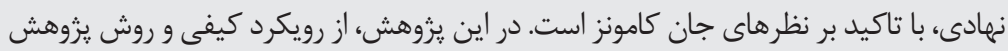

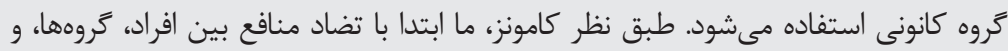

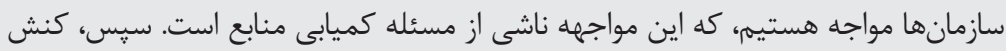

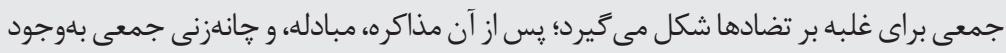

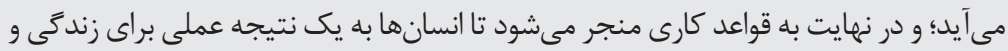

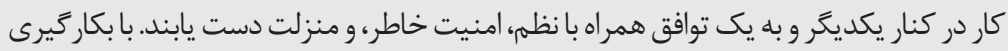

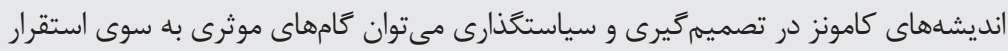

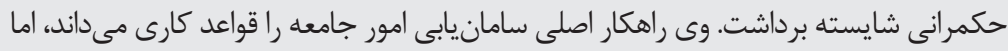

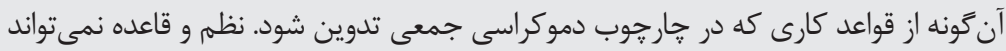

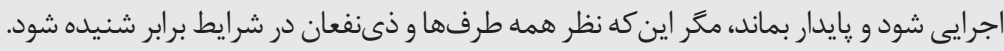

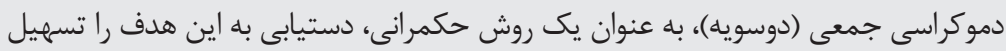
مى كند.

كليدوازهها: حكمرانى، اقتصاد نهادگرا، كنش جمعى، قواعد كارى، دموكراسى جمعى، جان راجرز كامونز. طبقهبندى J58, H10, G38 :JEL. 
شايد بتوان كفت كه قوىترين نظريهيرداز اقتصاد نهادى، جان راجرز كامونز' است. به همين دليل، مبناى اين يزوهش براى تدوين الكوى حكمرانى در قالب رويكرد نهادگرايى، بر اساس نظرهاى كامونز

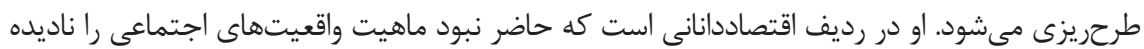
بحيرد (Lawson, 1999). وى همواره در جستجوى راهحل هاى ماهرانه نهادى متناسب با واقعيتهاى زمانه

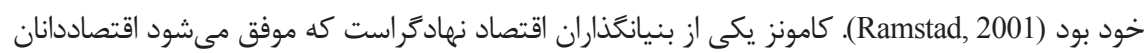

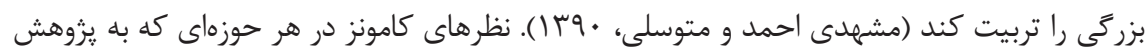

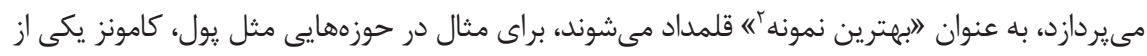

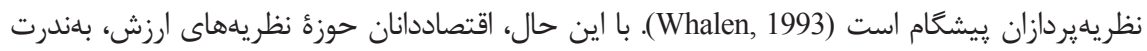

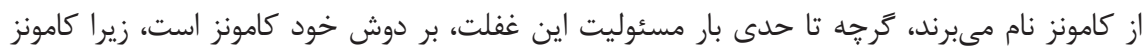

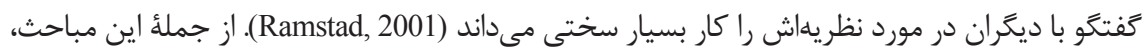

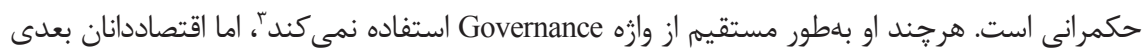

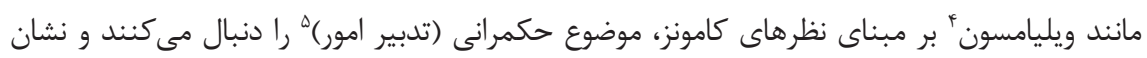

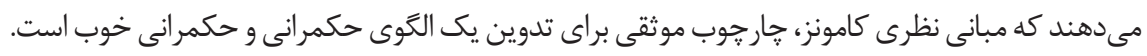

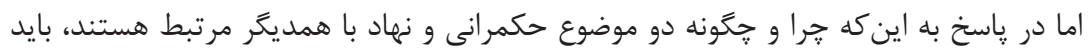
كفت كه يكى از اصلىترين دلايل توجه سالهاى اخير به مفهوم حكمرانى در سطح جهان دان را مى توان

1. John Rogers Commons (1862-1945)

2. Classic

ז. بايد توجه داشت كه استفاده از اصطلاح Governance در معناى امروزين آن، از دهه • • 191 ميلادى بلمرور

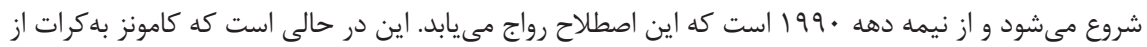

4. Oliver Williamson (1932-2020) وازههاى Govern و Governing استفاده مى كند. ه. از مشكلات واره Governance ترجمه صحيح آن است، زيرا با معادل هاى متعددى كه وجود دارد، مفاهمه فكرى را در

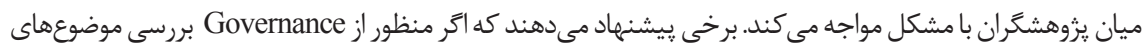

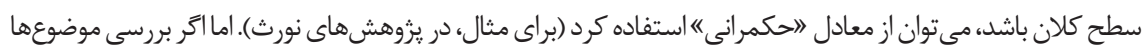

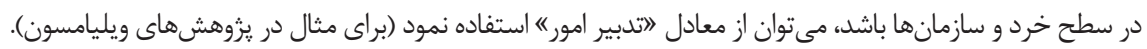

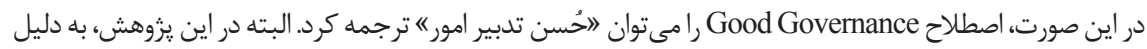

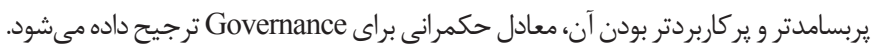


بازگشت علوم اجتماعى به رويكرد نهادى دانست. اين بازگشت از اوايل دهه • •199 ميلادى آغاز

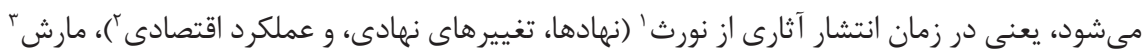

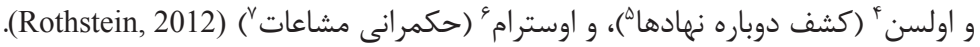
اگر واحد تحليل را در علم اقتصاد مبادله^ بدانيم، طبق نظر كامونز، هرگونه مبادله (از جمله مبادله كالاى عمومى)، فقط تبادل كالا نيست، بلكه يك بسته حقوقى است، نه يك انتقال صرف درف

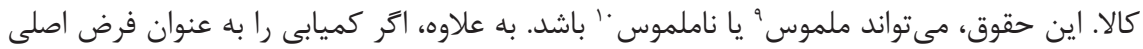
نظريههاى اقتصادى قلمداد كنيم، هر مبادلهاى حامل تضاد منافع بين دوطرف مبادله است. يس بـ بـ افراد (و سازمانها)، به دليل كميابى منابع، با يكديگر دجار تضاد" ميىشوند، ولى در بين اين تضادها،

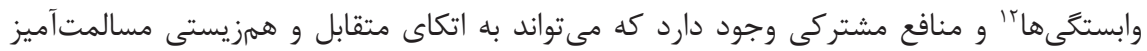

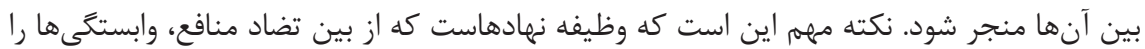

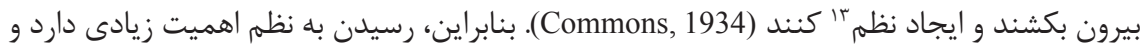

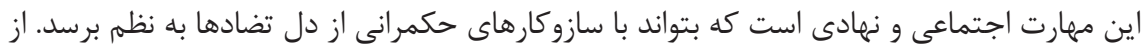

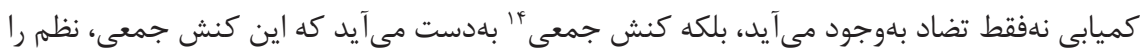

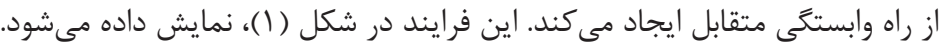

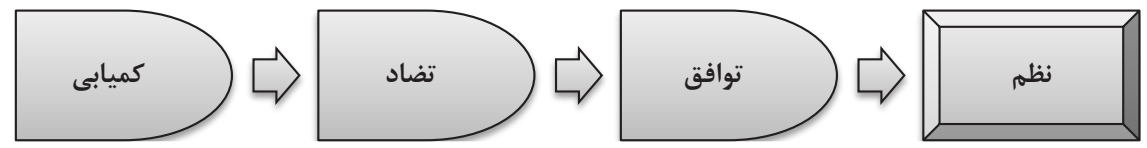

شكل 1: دستيابى به نظم با توافق، در شرايط كميابى منابع و تضاد منافع

1. Douglass Cecil North (1920-2015)

2. Institutions, Institutional Change, and Economic Performance

3. James Gardner March (1928-2018)

4. Johan Peder Olsen (1939- )

5. Rediscovering Institutions

6. Elinor Ostrom (1933-2012)

7. Governing the Commons

8. Transaction

9. Tangible

10. Intangible

11. Conflict

12. Mutuality

13. Order

14. Collective Action 
در مجموع با توجه به مبانى نظرى و تجربى، دستيابى به توافق، با وجود تضادها در هنگام تعاملها و مبادلههاى اقتصادى، شكاف دانشى مهمى است كه اين يزوهش به سهم خود در صدد تلاش براى رفع آن است. از آنجا كه در ساليان اخير، موضوع حكمرانى مركز توجه بسيارى از محافل علمى است،

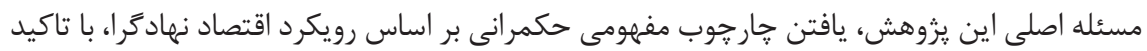

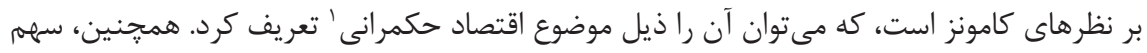
جديدى كه در اين يروهش صورت مى گيرد، ارائٔ يك مدل سيستم حكمرانى بر اساس نظام فكرى كامونز است، موضوعى كه تاكنون، دست كم در ايران، سابقهُ يروهشى ندارد.

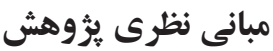

\section{كامونز و علم اقتصاد}

ابتدا بهتر است به اين :رسش پاسخ دهيم كه از نظر كامونز، علم اقتصاد بايد بر مبناى جه اصولى بنا

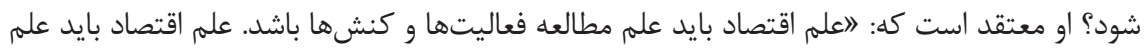

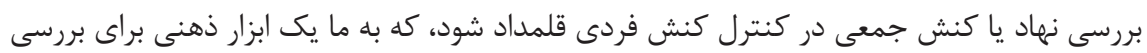

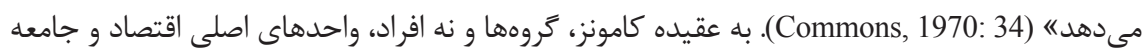
هستند، و آزادى، منزلت، و امنيت افراد از طريق كنش گروهى و همراه با اعمال كنترل، اعطاى آزادى،

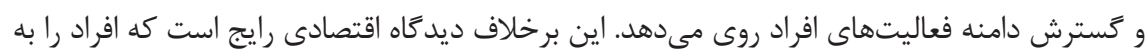

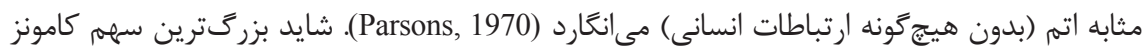

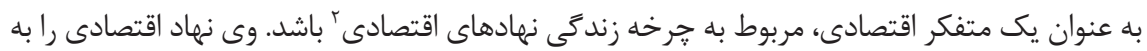

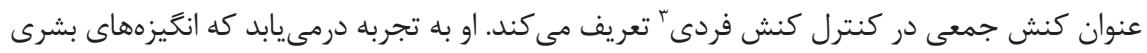
در مشاركتهاى جمعى و فعاليتهاى گروهى ظهور مى يابند (Perlman, 1970).

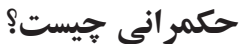

حكمرانى شامل تعاملهاى بين ساختارها، فرايندها، قوانين و مقررات، سنتها، و آداب و رسومى است كه نحوه اعمال قدرت، نحوه اتخاذ تصميمها، نحوه اظهار نظر ذىنفعان، و نحوه ارزيابى نتايج را مشخص

1. Economics of Governance

2. Life Cycle of Economic Institutions

3. Collective Action in Control of Individual Action 


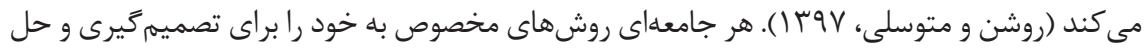
تعارضها دارد. حكمرانى يك امر اجتماعى است كه به فرايندهاى تعامل و تصميمثيرى در ميان فعالان

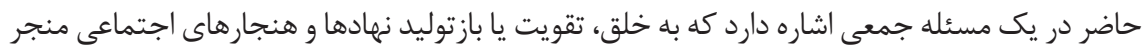
مىشود (Hufty, 2011). نقش حكمرانى در توسعه اقتصادى يك موضوع تحليلى مهرم است كه حتى

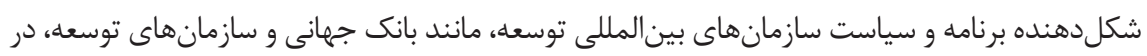

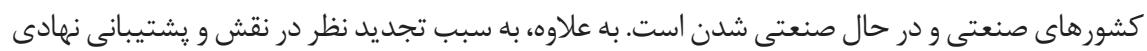

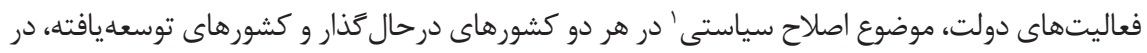
مباحث مربوط به حكمرانى نقش حياتى بازى مى كند (Ebner, 2009). اما جرا تاكنون تعريف مورد توافقى از حكمرانى حاصل نشده است؟ به به دليل مواردى همجِون بنيان هاى نظرى متفاوت و پيیجيدگى ابعاد مختلف موضوع، نه در ميان اقتصاددانان و نه در ميان ساير دانشمندان علوم اجتماعى، اجماع واحدى درباره تعريف حكمرانى بلوجود نيامده است. با اين حال،

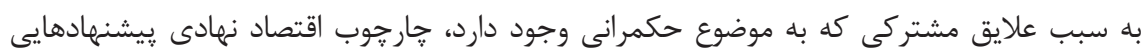
براى اين موضوع ارائه مىدهد: حكمرانى عبارت است از ظرفيت ماتريس نهادى يك كشور (كه شامل تعامل بين عاملان انفرادى، بنًَاهها، گَروههاى اجتماعى، سازمانهاى مداى مدنى، و سياستخذاران است)، به منظور به اجرا درآوردن يا وادار كردن به اجراى سياستهاى عمومى، و افزايش كيفيت همكارى بـى بهى

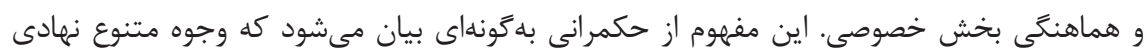

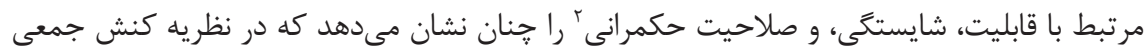
اولسون وجود دارد. همزمان، اين تعريف اجازه تجديد نظر در تنوع نهادى و دلالتهاى آن را براى

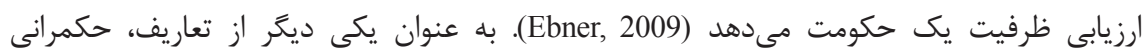
مجموعهاى از روشهايى است كه كارگزاران، امور مشترك خود را با آن مديريت مى كنيند. حكمرانى

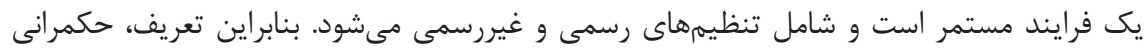
شامل: ״ا. وجود كارگزاران متعدد و فعال است؛ r. اين كارگزاران داراى مشكلات مشتركى هستند كه بايد حل شود؛ rا. در حكمرانى با فرايندهاى مستمر و نه محاسبههاى عقلايى موردى (يكدفعنهاى) مواجه هستيم؛ و أ. ترتيبات نهادى رسمى و غيررسمى براى حل مسائل مشترك وجود دارده .(Commission on Global Governance, 1995: 3) 


\section{كامونز بيشگام نظريه يردازى اقتصادى در حوزه حكمرانى}

هر جند تعاريف و مفاهيم ارائهشده توسط يزوهشگران درباره حكمرانى، طيف گستردهاى را شامل

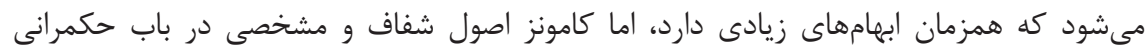
ارائه مىدهد كه راهگشاى سازمانها، جوامع، و كشورهاست. با بكاركيرى ايدهاى كامونز، در تصميمَّيرىها و سياستخذارىها مىتوان كامهاى موثرى به سوى استقرار حكمرانى شايسته برداشت. كامونز، مفاهيمى همجون تضاد، توافق، نظم، كنش جمعى، تشكل فعال، مبادله، و قواعد كارى را مركز

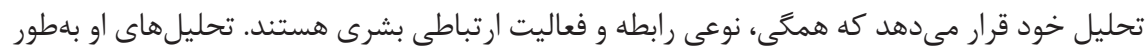
كامل منطبق با مفهوم حكمرانى است، زيرا منظور از اصطلاح Governance رابطه بين مردم و حاكمان

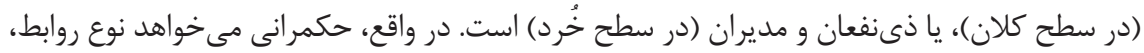

$$
\text { و نه دستخاه يا سازمان را توصيف كند (امامقلى يور و آسمانه، هوس آدان). }
$$

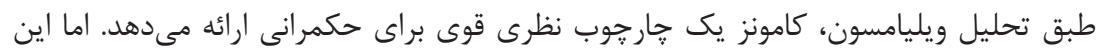

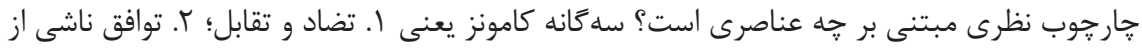

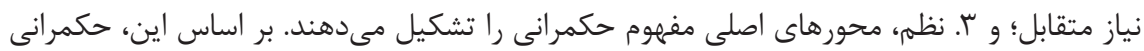

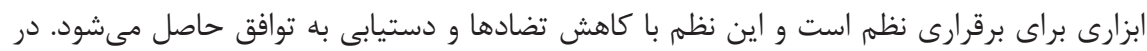

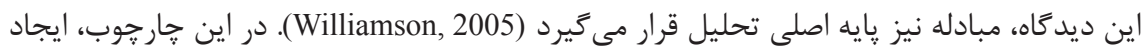

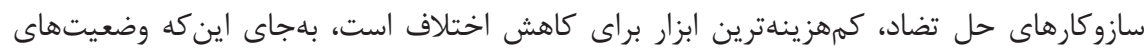

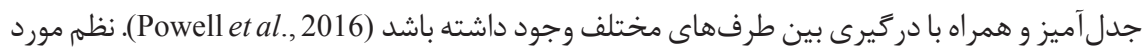
نظر كامونز، از طريق قواعد كارى رفع و رجوع مىشود. قواعد كارى، فصل مشتر كى مفهوم نهاد و مفهوم حكمرانى است. در واقع، قواعد كارى جرخه اصلى يِيوند نهاد و حكمرانى را شكل مى دهد (شكل ؟). جهره نهادها در قواعد كارى نمايان مىشود و اين قواعد كارى است كه بر مبادله و بر مناسبات قدرت تاثير مى كذارد و تعيين كنندة كيفيت سياسى و اخلاقى حكمرانى جوامع است. قواعد كارى وجود دارند كه مسئله نظم را حل كنند (Adelstein, 1998). 


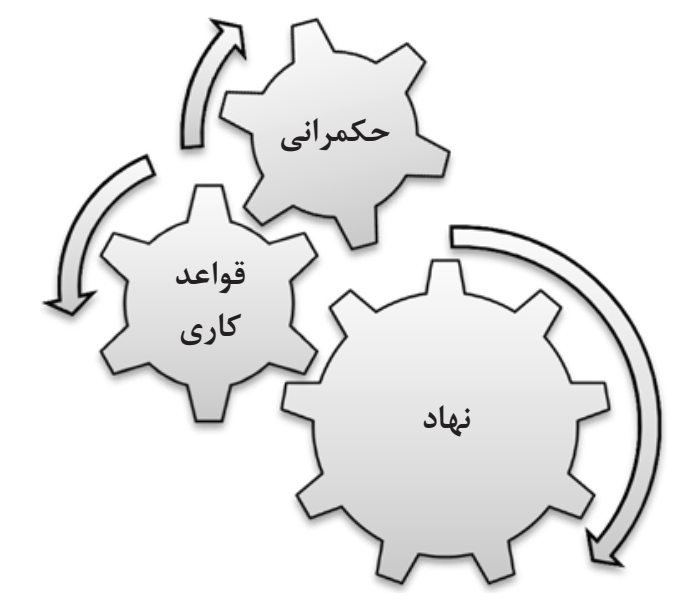

شكل r: قواعد كارى، حلقه ارتباطى مفهومى بين نهاد و حكمر انى

\section{روششناسى يثروهش}

كامونز يك يزوهشگر با رويكرد كيفى است. او با حضور در ميدان واقعى يروهش به بررسى مسائل

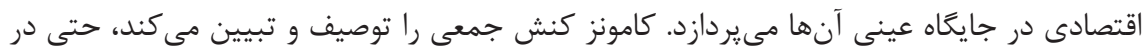

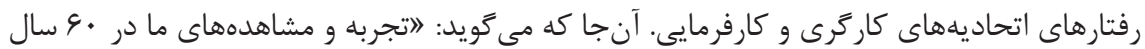
به ما مى آموزد كه كنش جمعى يك مفهوم جامع است. برخى افراد ممكن است اين رويكرد را اجتماعى مانى بدانند. هر جند كنش جمعى يك واقعيت مسلط در زندگى جوامع استه (Commons, 1970: 21). يزوهش كيفى بلهطور معمول به بررسى تجارب، ادراك، فهم، و تفسير افراد از وجوه مختلف زندكىشان جهى و واقعيت دنياى ييرامونى آنها تمايل دارد. يروهشهاى كيفى با مصاحبه و مشاهده بدون اندازهخيرى برى

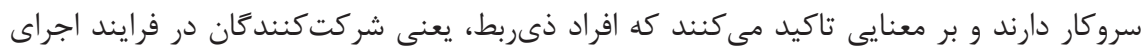

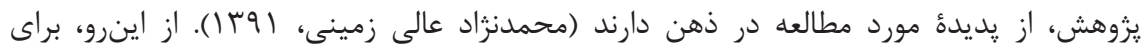
ياسخكويى به مسئله يزوهش از روش كيفى استفاده مىشود. براى انجام يروهش حاضر، روش گروه كانونى' بكار گرفته مىشود. همجنين، ابزار گردآورى دادهها مصاحبه گَروهى است. به علاوه، براى تجزيهوتحليل دادهها از تحليل محتوا استفاده مىشود، باططورى كه با كدَذارى باز، اجزاى مهرم مفهوم حكمرانى از ديد اقتصاد نهادى و نظرهاى كامونز بر اساس مصاحبهها و مبانى نظرى استخراج مىشوند. 1. Focus Group 
شيوه كروه كانونى براى يى بردن به درك افراد درباره يك موضوع ويزه بكار مىرود. اين روش يزوهش،

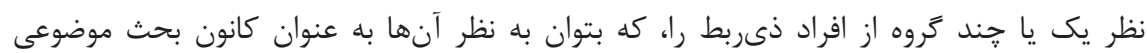

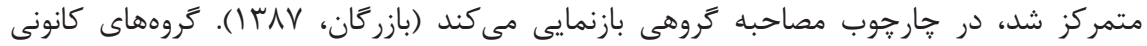
(متمركز)، بهطور رسمى سازمان مىيابند و در زمانى خاص گرد هم مى آيند تا ِيرامون يك موضوع

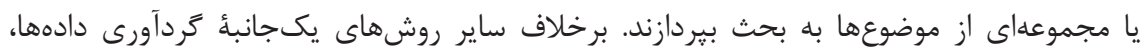

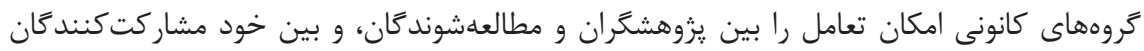

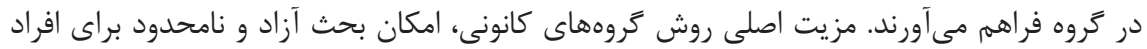

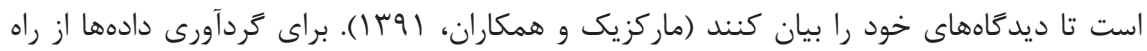

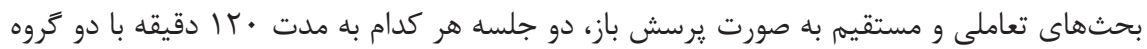
از متخصصان نهادكرايى، اقتصاد و روش يروهش در تير ماه عوسا و در محل موسسه يروهش و برنامهريزى آموزش عالى بركزار شد. در اين جلسهها، مدل اوليه حكمرانى كامونزى يِيش از جلسه

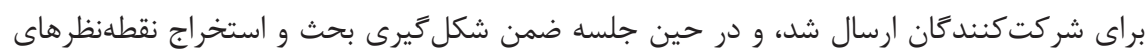
آنان در مورد مدل اوليه، بر اساس ريشننهادهاى ارائهشده، مدل ايجاد و اصلاح گرديد.

\section{تحليل يافتههاى يزوهش}

در ادامه، به تشريح مفاهيم محورى نظريههاى كامونز يعنى كنش جمعى، مبادله، و قواعد كارى

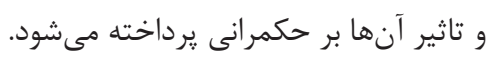

كنش جمعى جيست و جرا بررسى آن از نظر مبحث حكمرانى مهم است؟ اولسون كنش جمعى را קنين تعريف مى كند: اكنش جمعى عبارت است از كنشهاى انجامشده توسط دو نفر يا بيشتر (شامل

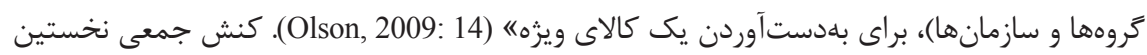
محور اصلى است كه كامونز تحليل مى كند. همجنين، بررسى كنش جمعى از آن جهت اهميت دارد كه

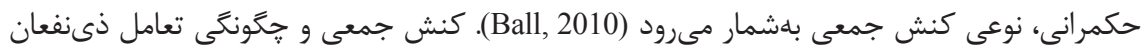
هر دو براى دستيابى به توافق و رفع تعارض ' از محورهاى اصلى نظرهاى كامونز هستند. بر اساس نظريه 
ذىنفعان، يك بنكاه يا سازمان در جهت كسب موفقيت بلندمدت، بايد خود را وسيلهاى براى برآوردن

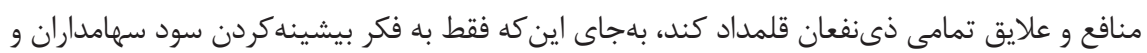

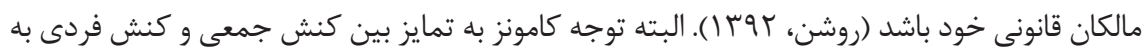
خاطر اين نيست كه كنش جمعى بلهور ساده در توصيف وضعيت اجتماعى كاربرد دارد. كامونز به مبادله

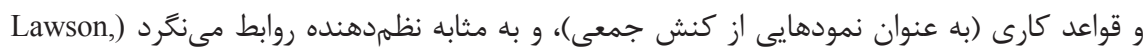
1999). در واقع، دوطرفه بودن فايده يا وجود منافع متقابل' در نتيجأ دادوستدهاى داوطلبانه، بنيان اساسى فهم علم اقتصاد است (Williamson, 2005)، و مورد تاييد و تاكيد كامونز.

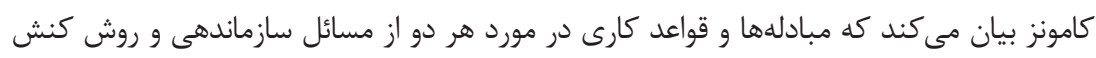

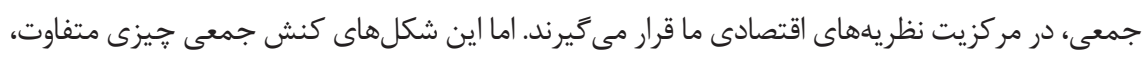

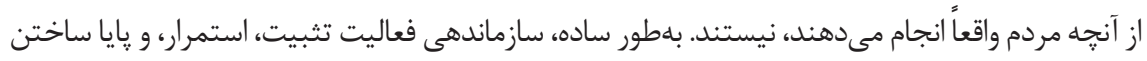

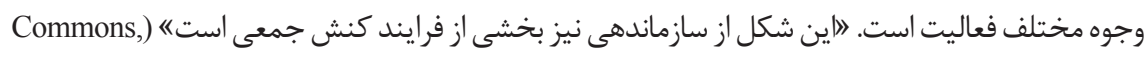

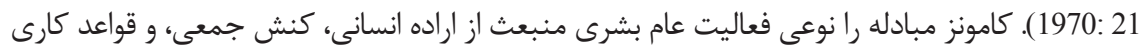
مى بيند (شكل ؟)، كه در همه امور (اعم از اقتصادى، سياسى، فرهنكى، و دينى)، براى سازماندهى و استمرار فعاليتها، سارى و جارى است و ناشى از يك نياز مشترك بشرى يعنى دستيابى به منافع متقابل است.

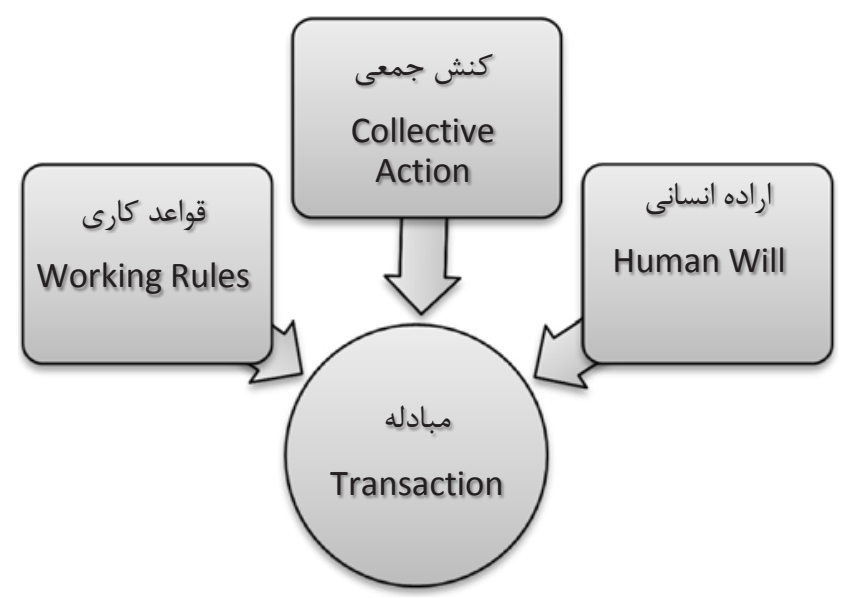

شكل "ّ: سه عنصر تشكيلدهنده و لازم براى انجام مبادله 
همزمان، مىتوان نمودى از كنش جمعى در جانهزنى جمعى' مشاهده مىشود. در اين حالت،

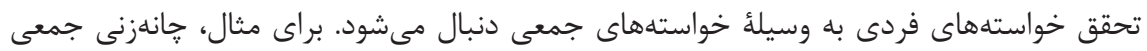
در روابط بازار كار با نمايندگان دو سازمان، يعنى اتحاديههاى كارگرى و اتحاديههاى سرمايهداران

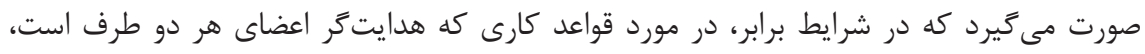

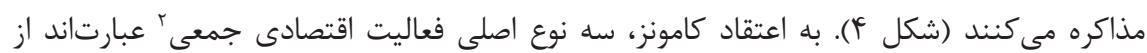
شركتها، اتحاديههاى كارگرى، و احزاب سياسى (Commons, 1970). جالب است كه كامونز فعاليت احزاب سياسى رانوعى فعاليت اقتصادى جمعى قلمداد مى كند و اين تعبير، تاييدى است بر نظر او

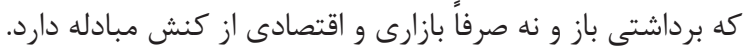

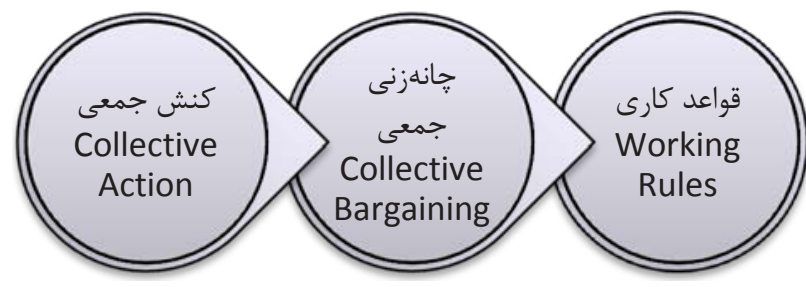

شكل †: قواعد كارى، نتيجه كنش جمعى و خانهزنى جمعى

هنحامى كه جانهزنى جمعى به يك رويه قانونگذارى تبديل شود، نوعى دموكراسى بلوجود مى آيد

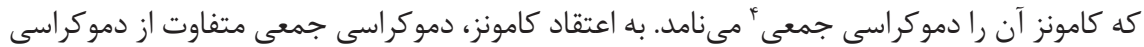
فردىه مورد نظر اسميت و متفاوت از ديكتاتورىهاى ارويايى و آسيايى است (Commons, 1970). بدين ترتيب، مىتوان كفت طبق نظر كامونز، ابتدا با تضاد منافع بين افراد و زروهها مواجه هستيم كه خود آن ناشى از مسئله كميابى منابع است. سيس، كنش جمعى براى رفع و غلبه بر تضادها شكل

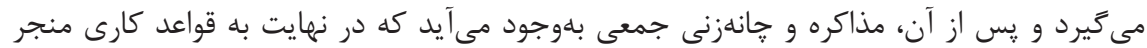
مىشود، تا انسانها به يك نتيجه عملى براى زندگى در كنار يكديكر دست يابند (شكل ه). به كَتها

1. Collective Bargaining

2. Collective Economic Action

3. Law-Making Procedure

4. Collective Democracy

5. Democracy Individualistic

6. Adam Smith (1723-1790) 
كامونز، ممكن است اين راهحل (يعنى خانهزنى جمعى براى دستيابى به قواعد كارى مورد توافق) ايدهآل، يا منطقى يا انقلابى نباشد. ولى اين روش كشفى است كه با بررسى و مذاكره بهدست مى آئيد.

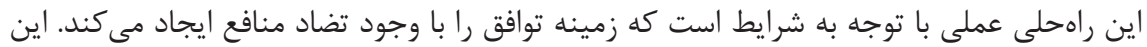

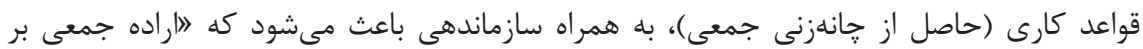

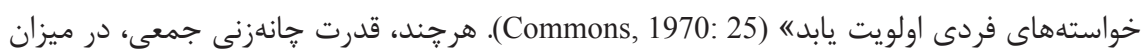
قدرت كنترل منابع از سوى طرفهاى مختلف مذاكره متجلى مىشود (Marangos, 2007).

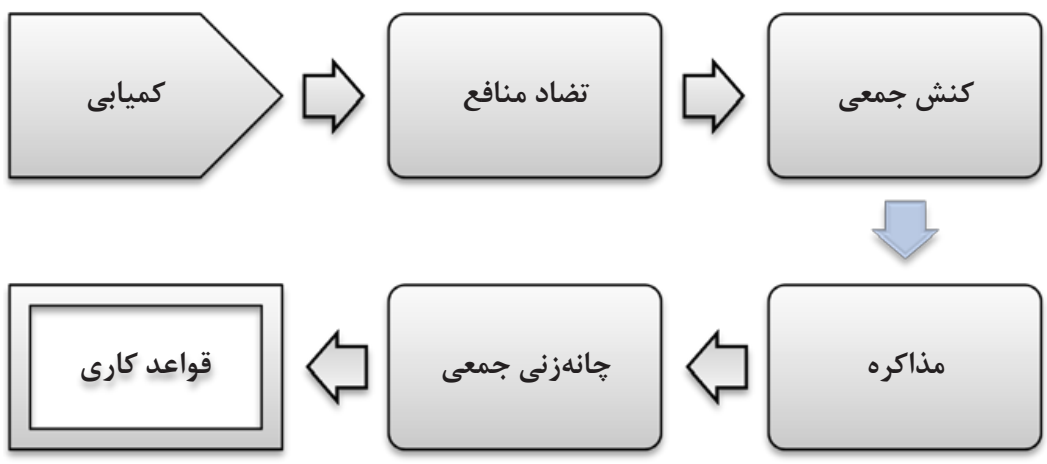

شكل ه: مراحل دستيابى به توافق از كميابى تا قواعد كارى

كامونز مىخواهد كه اتحاديههاى اقتصادى و تجارى (نظير كارگرى و كارفرمايى)، تا جايى كه

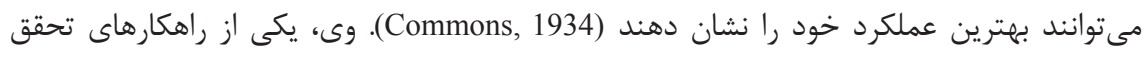
اين هدف را كنش جمعى دوطرفه مىداند. در كنش جمعى دوطرفه، مىتوان روانشناسى فر فرايند

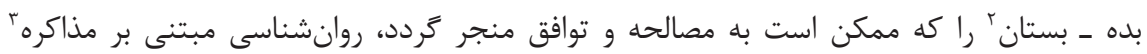

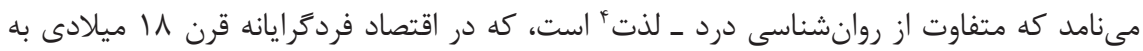

1. Two-Sided Collective Action

2. The Psychology of Give-and-Take Process

3. Negotiational Psychology

4. Pleasure-Pain Psychology 
بعد وجود داشت. البته برخى (مانند وبلن)، كنش جمعى كارفرمايان و كاركران را محكوم مى كنند، و برخى ديگر نيز (مانند اسميت)، اينگ گنه اتحاديهها را به دليل ايجاد انحصار محكوم مى كنند. اما در اواخر قرن 19 ميلادى، تمايز مفهومى بين كنش جمعى يكسرفه و كنش جمعى دوطرفه (جانهزنى جمعى) بهوجود آمد. لادر كنش جمعى دوطرفه نمايندكان هر دو طرف بر انتخابها و خواستههاى خود مذاكره مى كنند" (Commons, 1970: 29). بهطور معمول، اقتصاددانان ادعا مى كنند كه در تجارت آزاد، جانهزنى بينفردى' وجود دارد،

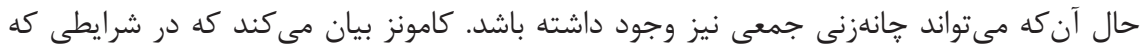

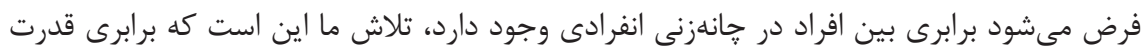

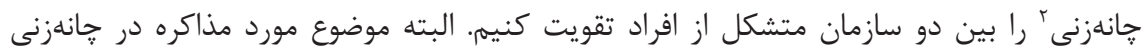
جمعى و بين سازمانهاى متشكل، مبادله و دادوستد كالاها نيست، بلكه ساخت و ايجاد قواعد كارى مورد جانهزنى قرار مى گيرد. اين قواعد كارى در صدد اهدايت و حكمروايى همه امور مربوط به كارفرمايان و كارگران، و موضوعهايى مثل قوانين استخدام و اخراج، نرخ دستمزد، ميزان ساعات

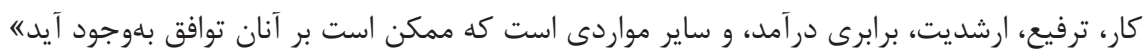

.(Commons, 1970: 29)

كنش جمعى يكىطرفه، جانهزنى جمعى محسوب نمىشود. در روسيه شوروى، ديكتاتورى

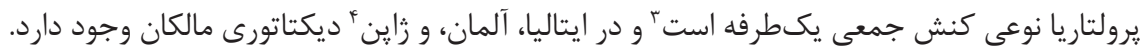
كامونز در ادامه مىنويسد: من كنش جمعى دوطرفه، دوسويه، و تعاملى را دموكراسى جمعى ميىنامه.

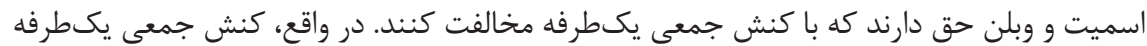

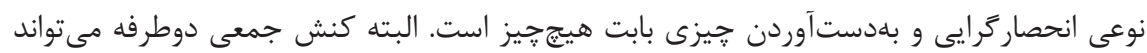

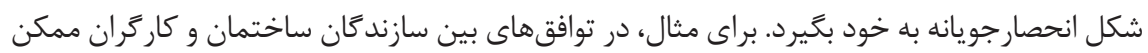
است مردمى كه خواهان مسكن ارزان هستند، متضرر شوند. در اينجا صاحبان سرمايه و كارگران

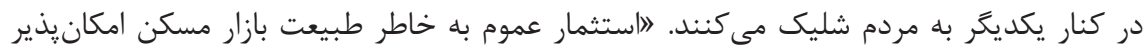

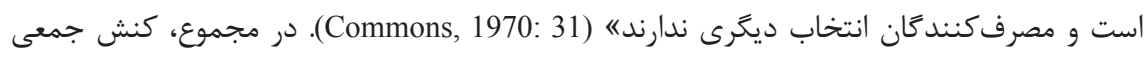

1. Individual Bargaining

2. Equality of Bargaining Power

ب. با توجه به محتوا، احتمالاً كتاب اقتصاد كنش جمعى The Economics of Collective Action كامونز در

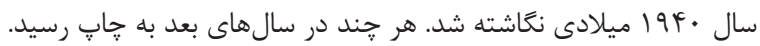

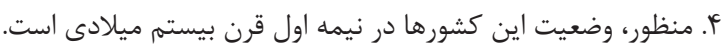


جِيزى بيش از كنترل كنش فردى است. كنش جمعى به معناى آزادى و گسترش ميدان كنش فردى در انتخاب و در اقدام است (شكل ؟). به عبارت ديخر كنش جمعى، ابزارى براى آزادى است. و تننها

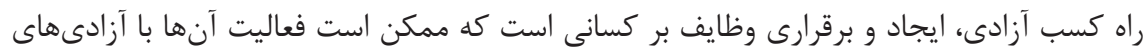
ديكران متداخل گردد، همجنان كه المردم آمريكا با تحميل وظايفى بر بردهداران از نظام بردهدارى خلاصى يافتنده (Commons, 1970: 34-35).

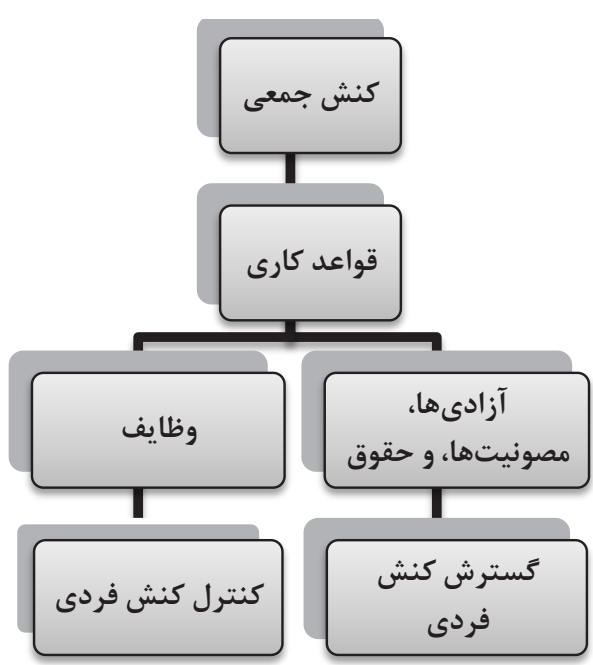

شكل 9: قواعد كارى: آزادىبخش و محدود كننده

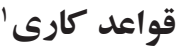

همه مبادلهها، به دنبال كنترلهاى قانونى هستند و در همه روابط بين طرفها، امورى همجٍون تضاد منافع، وابستگى متقابل، و نياز به برقرارى نظم وجود دارد (McLaughlin, 2010). اما يك نظم و قاعده نمى تواند به اجرا درا آيد، المگًر اين كه نظر همه طرفها در شرايط برابر شنيده شوده (Commons, 1970:26).

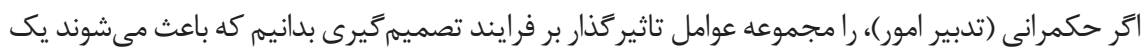
خطمشى، تدوين و اجرا شود، قواعد كارى يكى از اركان اصلى حكمرانى است. 
در يزوهش حاضر، فرض بر اين است كه قواعد كارى مهمترين حلقه اتصال دو مفهوم حكمرانى و نهاد است. قواعد كارى عبارت است از مجموعهاى از قوانين، مقررات، و آداب و رسوم كه انجام يكى ركى

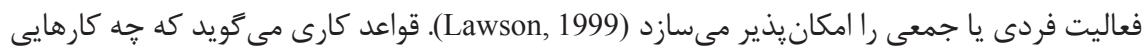

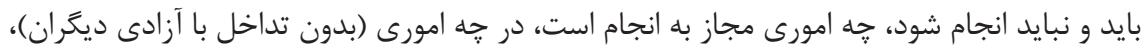
آزادى عمل وجود دارد، و جه امورى جزو حقوق و صلاحيتهاى افراد است و مى توانند انجام شوند. در واقع، قواعد كارى كه ميان تشكلهاى جمعى و دولتها وضع مىشود، مشخص كننده حقوق، وظايف، و

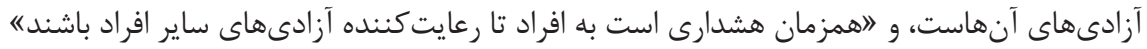
(Commons, 1924:6)

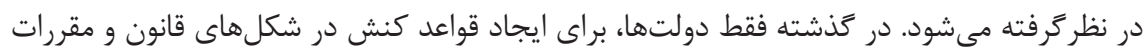
اجرايى يا احكام قضايى صاحب قدرت بودند. اما امروزه، اتحاديههاى كارفرمايى و كارگرى وظيفه

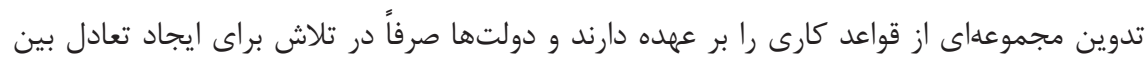
اتحاديههاى كارفرمايى و كاركرى هستند. اين قواعد كارى، موضوع كانونى علم اقتصاد است. الدولتها

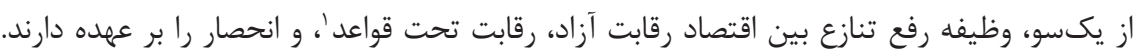
دولتها` وظيفه دارند كه تعادل را بين شاخههاى قانونگذارى، اجرا، و دستخاه قضايى ايجاد كنند، و از

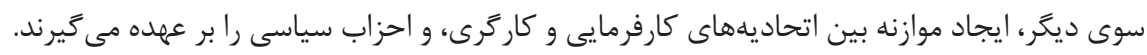

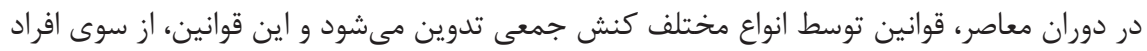

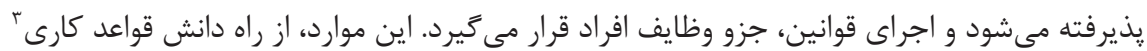

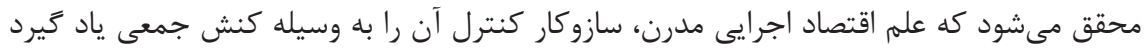

.(Commons, 1970: 129-130)

\section{Regulated Competition}

r. شايد در اينجا منظور كامونز از دولتها يا Governments، ناظر بر حكومتها يا States است. زيرا وظيفه ايجاد تعادل بين شاخههاى قانونكذارى، اجرا، و دستكاه قضايى به عهده حكومت State است و نها مانه

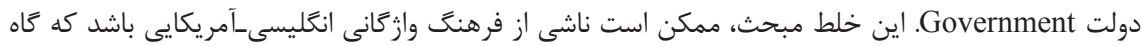

3. Knowledge of Working Rules 


\section{مدل حكمرانى در جار جوب نظرى كامونز}

يرسشى كه پيش مى آيد اين است كه اخر قرار باشد يك مدل حكمرانى بر اساس نظرهاى كامونز

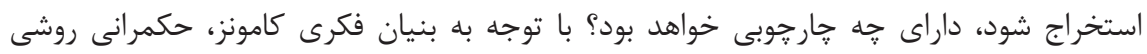
براى برقرارى نظم است و اين نظم با كاهش تضادها و دستيابى به توافق حاصل مىشود. اين مدل حكمرانى با استفاده از جهار مفهوم پايهاى ديكر در منظومه فكرى كامونز يعنى كنش جمعىى، تشكل فعال، مبادله، و قواعد كارى به صورت عملياتى درمى آيد. بر اساس مفاهيم نظرى انديشههاى كامونز،

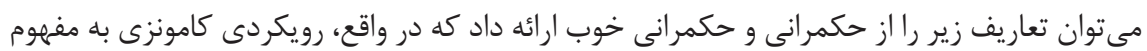
حكمرانى و حكمرانى خوب است: حكمرانى: روش انجام كنش جمعى و تعامل (مبادله)، و شيوه تدوين و اجراى قواعد كارى براى

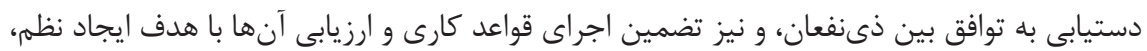
سازماندهى، و هماهنكى است. حكمرانى خوب: روش انجام كنش جمعى (مبتنى بر كنش جمعى دوسويه)، و تعامل (مبادله)، و شيوه تدوين قواعد كارى (مبتنى بر دموكراسى جمعى)، براى دستيابى به توافق بين ذىنفعان، و و

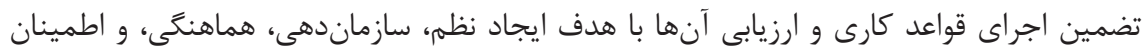
خاطر است.

با تدقيق در نوشتههاى كامونز، مىتوان ديدكاه او را در مورد حكمرانى با نگاه سيستمى توضيح

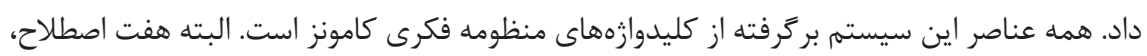
كه ممهمترين و اصلىترين مفاهيم نظريههاى كامونز را تشكيل مى دهندئ عبارتاند از ا. تضاد؛ ك. ك.

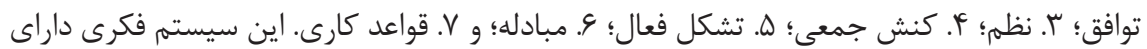

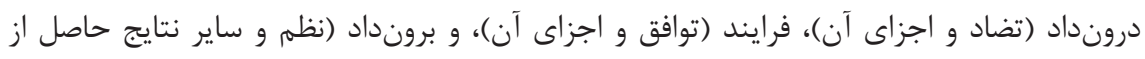
توافق)، به علاوه محيط و بازخورد است (شكل V). در ادامه، به تشريح اين مدل سيستمى حكمرانى لنى

$$
\text { يرداخته مىشود. }
$$

محيط: اين سيستم از نهادهاى غيررسمى يعنى فرهنَ و آداب و رسوم اجتماعى تشكيل مىشود. به هر كنش مشترك مثل آداب و رسوم بهطورى كه كموبيش در صدد كنترل بر كنش فردى

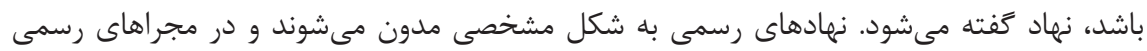
فعاليت مى كنند. در حالى كه نهادهاى غيررسمى مانند قواعد مشترك اجتماعى هستند كه بيشتر 
نانوشته و غيرمدون، ايجادكننده و اجراكننده تشويق و مجازاتهاى غيررسمى هستند. قواعد نهادهاى

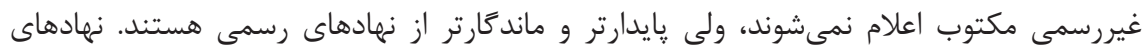
غيررسمى به رسوم فرهنكى و نهادهاى رسمى به قواعد اجبارى يك حكومت اشاره دارد.

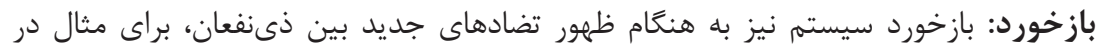

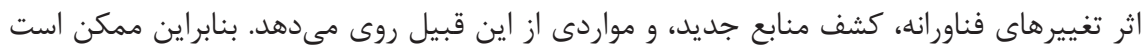

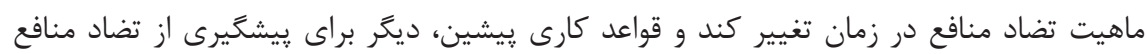
بسنده نباشند. هنًَامى كه تضادهاى جديد ظهور مى كنند، هر يك از طرفها قادر است كه براى رفع در گيرىها، شيوههاى مرسوم متناظر با منافع خودش را بازشناسى كند. تغيير در قواعد كارى مستلزم تغيير در ماهيت روابط يا ماهيت مبادله است. بخش درونداد سيستم: تضاد محور اصلى درونداد سيستم را تشكيل مىدهد. ساير اجزاى درونداد كه متاثر از يا تاثيرگذار بر مسئله تضاد هستند عبارتاند از اراده انسانى، فعاليت بشرى، كميابى، قدرت، كنش جمعى، و تشكل فعال. در زير، توضيح كوتاهى از اين مفاهيم ارائه مىشود.

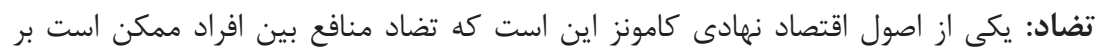
ساير ابعاد ارتباطى غلبه يابد. ضمن اين كه ماهيت مبادلهها به شكلى است كه بين طرفهاى مختلف تضاد منافع بلوجود مىآيد (بين خريدار و فروشنده، يا بين كاركر و كارفرما يا استخدامكننده و و

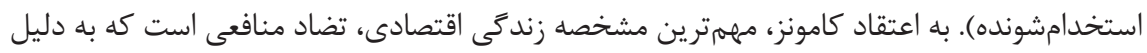

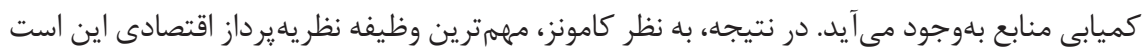
كه توصيف علمى براى فرايندى ارائه دهد كه به واسطه آن از دل تضادها، نظم و توافق ظهيعور كند. در همه روابط بين طرفهاى مختلف در يك مبادله، امورى همجون تضاد منافع، وابستخى متقابل، و و ونه

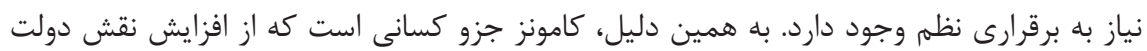
براى ايجاد تعادل بين منافع متضاد كروههاى مختلف حمايت مى كند. وى ايجاد اجتنابنايذير تصادم

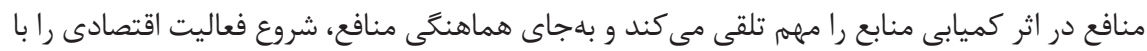

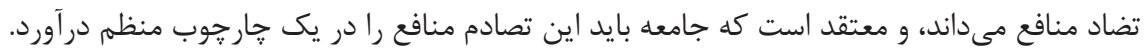

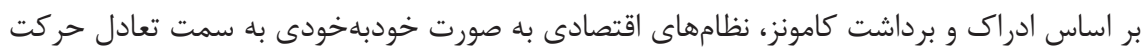

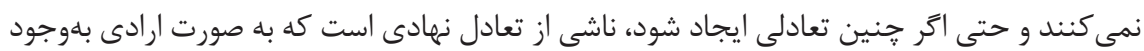
مى آيد، كه خود از تطابقها و تنظيمات قواعد كارى نشئت ميى خيرد. 
فعاليت بشرى: در واقع نمودى از اراده انسانى در عمل است. در اقتصاد نهادى مورد نظر كامونز، نخستين واحد تحليل، نوعى از فعاليت بشرى يعنى مبادله است و تمركز اين رويكرد، بر مشاركتكنندكان در مبادله (ذىنفعان)، و روشى است كه خواستههاى متضاد خود را رل حلوفصل

كميابى: اقتصاد سياسى كامونز به مطالعه اين موضوع مى يردازد كه جَّونه افراد پيخير نفع شخصى در دنياى مواجهه با مسئله كميابى، تشويق يا ناگزير مىشوند كه راههايى براى تحقق علايق

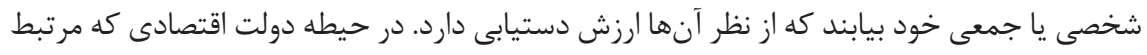
با قدرت اقتصادى است، قدرت كميابى و ممانعت افراد از حقوق مالكيت و محروم كردن افراد از آن

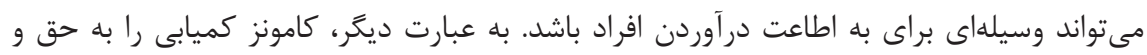

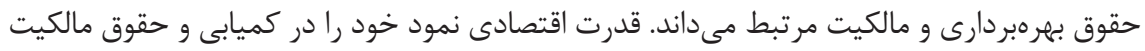

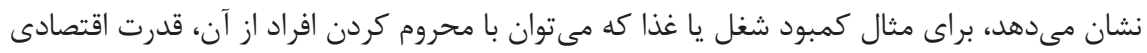
را اعمال كرد. گر حه هوا براى تنفس، در دسترسترين منبع در ميان همه منابع طبيعى است، اما هوا ارزش كميابى ندارد، بلكه داراى ارزش مصرفى است. ارزش كميابى با حقوق مالكيت كره مي خورد.

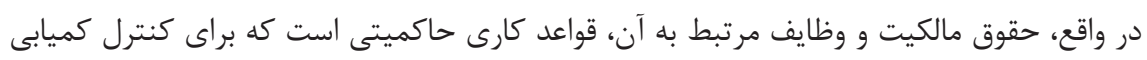
بكار مىرود.

قدرت: وازه قدرت به معناى تاثير حذاشتن بر اراده ديغران است. بنابر نظر كامونز، (دستكم)

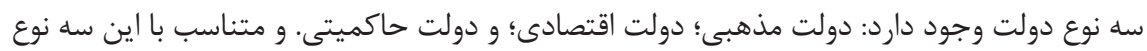
دولت، سه نوع قدرت هست: قدرت اخلاقى؛ قدرت اقتصادى؛ و قدرت حاكميتى' (قدرت فيزيكى). براى مثال، در اقتصاد نهادى بهجاى اين كه بهطور ساده قيمت و تخصيص منابع را كاركردى از عرضه

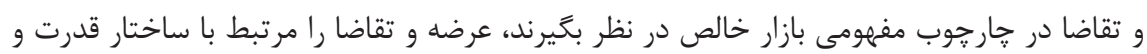

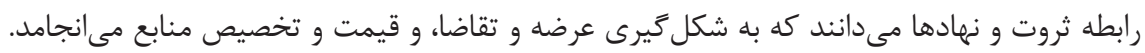
به همين ترتيب، خود ساختار قدرت نيز مرتبط با حقوق قانونى است. توجه به مفهوم قدرت در در مدل حكمرانى از آنجا اهميت دارد كه حكمرانى را مى توان تخصيص (رسمى يا غيررسمى) قدرت دانست.

ا. حكومت يا State متفاوت از حاكميت يا Sovereignty است. يك حكومت ممكن است مستقر باشد، اما

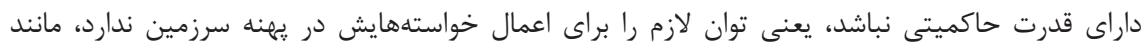

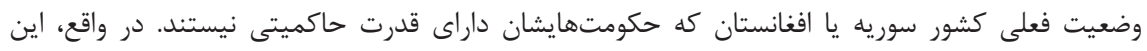
كشورها حكومت دارند، اما حاكميت ندارند. 
كنش جمعى (يكسرفه و دوطرفه): در اواخر قرن 9 إميلادى تمايز مفهومى بين كنش جمعى

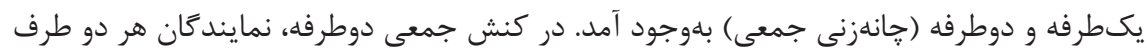
روى انتخابها و خواستههاى خود مذاكره مى كنند. كنش جمعى يكىطرفه، جانه نمىشود. كامونز كنش جمعى دوطرفه و تعاملى را دموكراسى جمعى مى نامد.

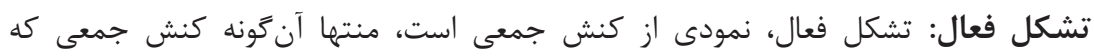
سازمانيافته باشد. نهادهاى رسمى و سازمانها نمونه هايى از تشكل فعال هستند. در ميان ايدهاى سنى مهرى كه كامونز در مورد مبحث اقتصاد حكمرانى ارائه مى دهد، توجه و علاقه او به يديده لاتشكل

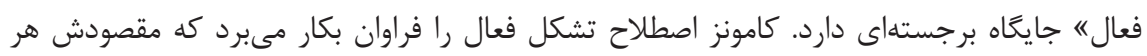

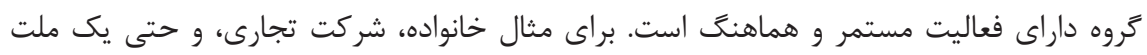
همگى نمونهاى از تشكل فعال هستند. كنش جمعى در دوران معاصر در قالب اتحاديههاى كارفرمايى،

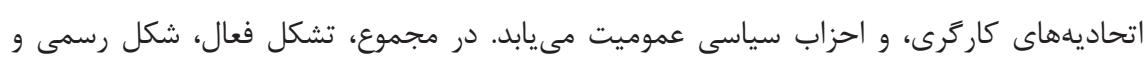

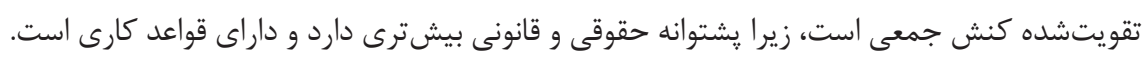

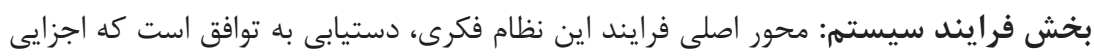

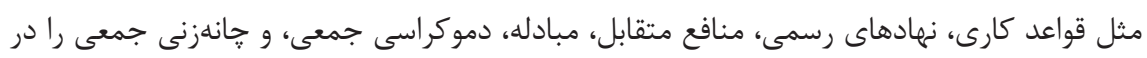

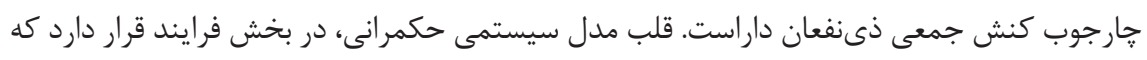

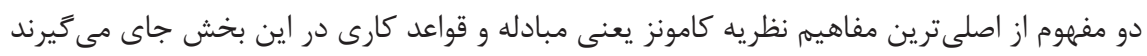

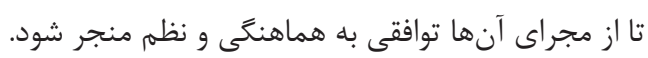

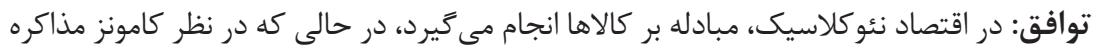

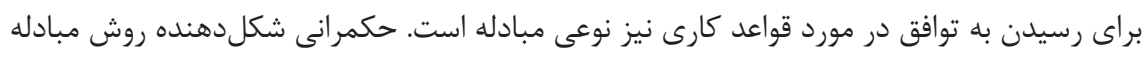

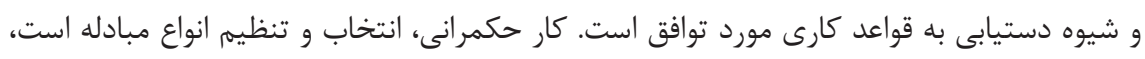
بلهورى كه بيشترين بروندادهاى مثبت را به همراه داشته باشد. بر اساس اين، حكمرانى ابزارى دورى

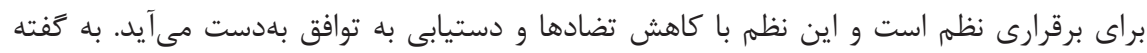

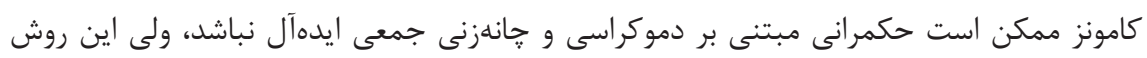

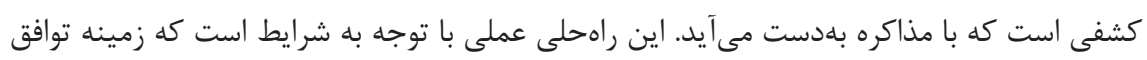

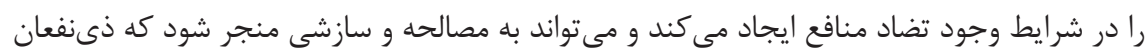

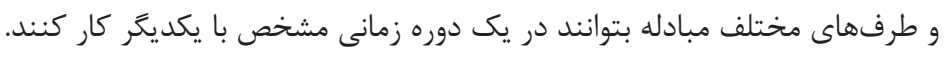
قواعد كارى: مبادله به همراه قواعد كارى ساختاردهنده و تسهيل 
قواعد كارى اصلىترين ابزار اعمال حكمرانى است. كامونز توصيه مى كند كه نظريههاى اقتصادى بايد

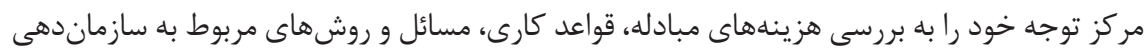

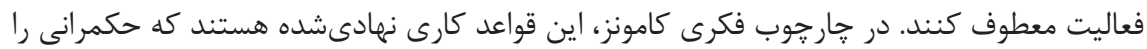
در حوزه مبادلههاى افراد مشاركت كننده در فعاليتهاى اقتصادى شكل مى دهند، نه فرايند طبيعى.

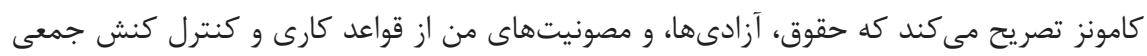
بر كنش فردى ناشى مىشود. در واقع، اين كنترل اطمينان از انجام وظايفى است كه بهطور يكسان

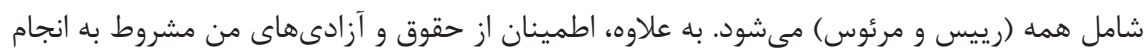

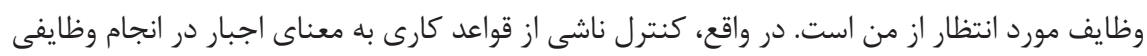

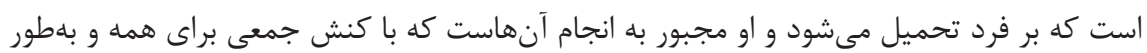

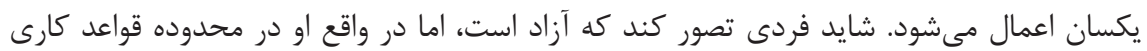

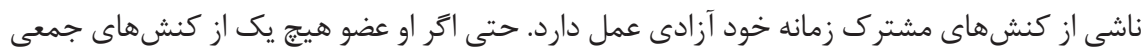
سازمانيافته نباشد، خود را در مقابل كنشهاى جمعى غيرسازمان يافته مثل آداب و وردو رسوم، عادتها (اجتماعى)، و سنت ها خواهد ديد.

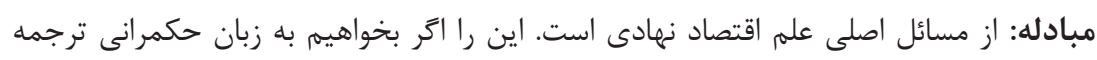

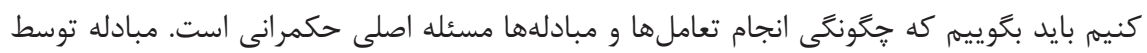

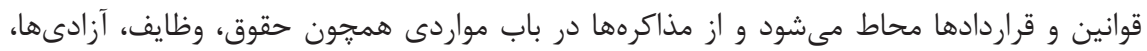

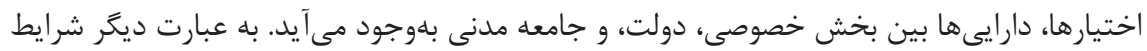
مبادله، برونداد مذاكره است. كامونز تاكيد دارد كه مبادله مورد نظر او دربرگيرنده روابط انسان با بانيا انسان (اشخاص با اشخاص) است. به اين نوع از مبادله، مبادلههاى كامونزى كَفته مىشود. مبادلهها

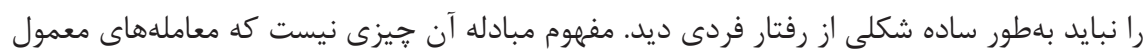

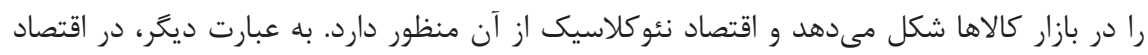

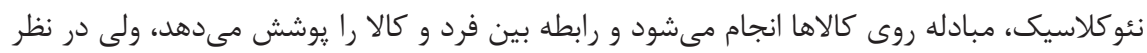
كامونز، مبادله عبارت است از مذاكره براى رسيدن به توافق در مورد قواعد كارى. در واقع، موضوع مباء

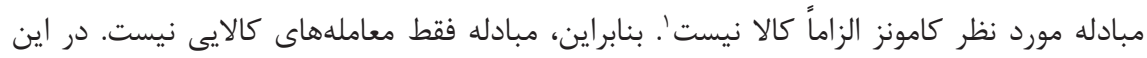
جارجوب، مبادله عبارت است از مذاكره بين اشخاص روى حقوق مالكيت، وظايف، و آزادىهاست.

ا. از اينرو، حهبسا بهتر است در متون فارسى اقتصادى، در ترجمه وازّان Exchange و Transaction بسته

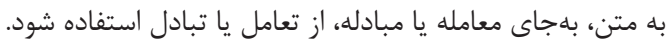


اين حقوق و وظايف (قواعد كارى)، در قالب مبادله و در فرايند مذاكره بين طرفهاى مختلف، حتى يیش از اين كه نيروى كار كالايى توليد كند يا مصرف كنندهاى كالايى مصرف نمايد يا كالاها به صورت

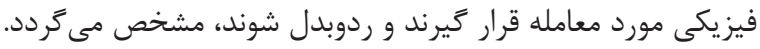

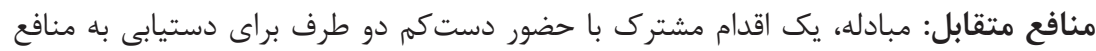

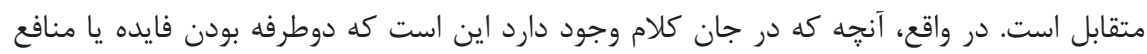
متقابل در نتيجه دادوستدهاى داوطلبانه، بنيان اساسى فهمم علم اقتصاد است. كامونز مبادله را نوعى فعاليت عام بشرى منبعث از اراده انسانى، كنش جمعى، و قواعد كارى مىبيند كه در همه امور همراه

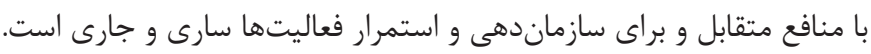

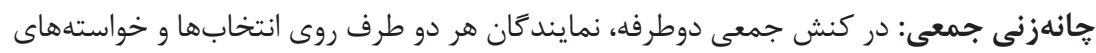

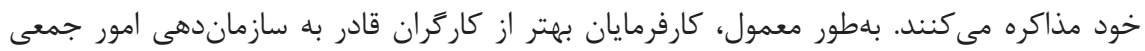
خود هستند. جاهايى كه اتحاديههاى كارگرى شكست مى خورند، اعضاى اتحاديه و كارگران به صورت

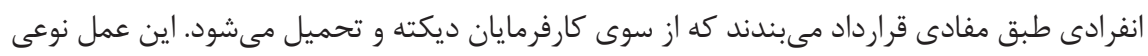
كنش جمعى يكىطرفه است. كنش جمعى يكىطرفه، خانهزنى جمعى محسوب نمى شودى دموكراسى جمعى: همه انواع مبادله، به دنبال كنترلهاى قانونى هستند و در همه روابط بين طرفها نياز به برقرارى نظم وجود دارد، اما يك نظم و قاعده نمىتواند به اجرا در آيد، مكر اين كه نظر

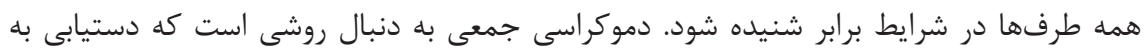

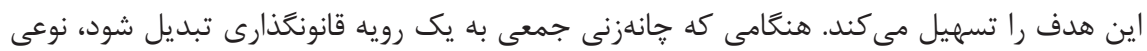
دموكراسى بهوجود مى آورد كه كامونز آن را دموكراسى جمعى مىنامد.

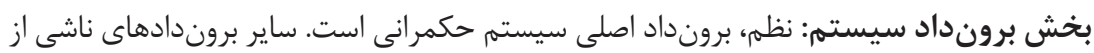

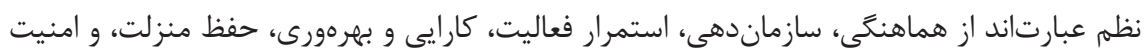

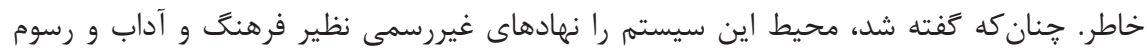
اجتماعى (نهادهاى غيررسمى) تشكيل مىدهد. به علاوه، بازخورد در اين سيستم با اعضاى هر يك رهي از تشكلهاى فعال ذىنفعان صورت مى گيرد و مشكلات جديد، در مذاكرهها و تعاملها (مبادلهانها)، مورد بحث قرار مى گَيرد. نظهم: كنش جمعى، شاكله اصلى نهاد است و ايجاد هماهنگى و نظم در كنش جمعى، مسئله حكمرانى است. كامونز به شكل كستردهاى به راهكارهاى ايجاد نظم از دل تضادها توجه دارد. توجه وى به تمايز بين كنش جمعى و كنش فردى به خاطر اين نيست كه كنش جمعى بهطور ساده در 
توصيف وضعيت اجتماعى كاربرد دارد. كامونز به مبادله و قواعد كارى (به عنوان نمودهايى از كنش جمعى)، به مثابه نظمدهنده روابط مىنگرد. به عبارت ديخر منشاى نظم، كنترل جمعى در كنترل رفتار فردى از راه قواعد كارى است.

سازماندهى: كامونز بيان مى كند كه در مر كز نظريههاى اقتصادى، مفاهيم مبادله و قواعد كارى

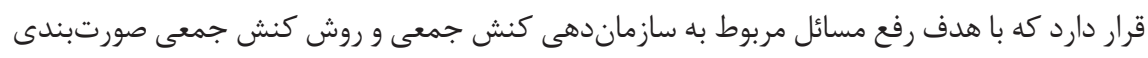

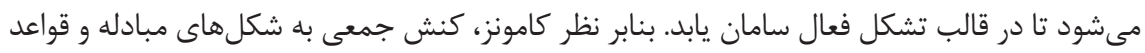

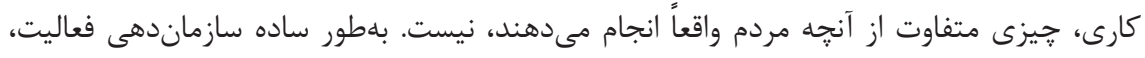
تثبيت و يايا ساختن وجوه مختلف فعاليت است. اين شكل از سازماندهى بخشى إنى از فرايند جمعى است. استمرار فعاليت: كامونز در مقابل و برخلاف رويكرد ارتدوكس اقتصادى كه نغاه سادهاى به ֶارادايم مبادله بازارى و تخصيص منابع دارد، بر استمرار و تداوم روابط مبادلههاى كالايى تاكيد

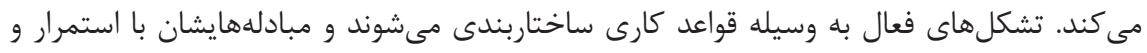
دوام يابر جا مى مانند.

حفظ منزلت و رهايى از سرسيردگىى: كامونز عميقاً تحت تاثير اين موضوع قرار مى گيرد كه

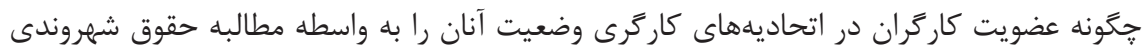

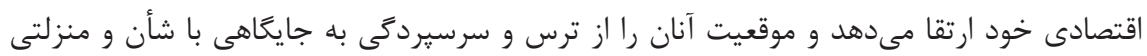
بيشتر و شجاعت بالاتر تغيير مى مهدد. امنيت خاطر: كامونز معتقد است كه مبادله بايد تحت شرايطى انجام شود تا براى انتظارهاى

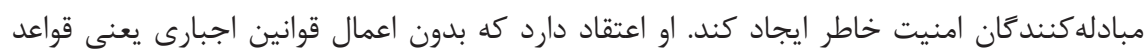

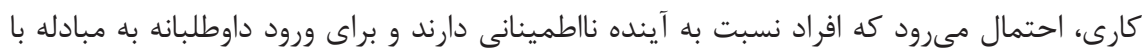
ديخران تمايلى از خود نشان نمى دهند. كاركرد قواعد كارى، ايجاد اعتماد و اطمينان و پِيشبينى يذير شدن، كنترل، و قاعدهمند كردن رفتار طرفهاى ديگر است. همجنين، آزادى فردى به وسيله كنش

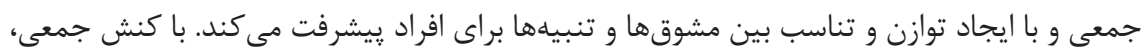

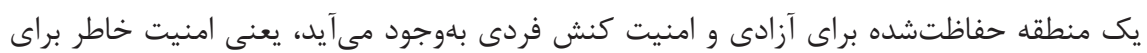
افراد و سازمانها ايجاد مىشود. 


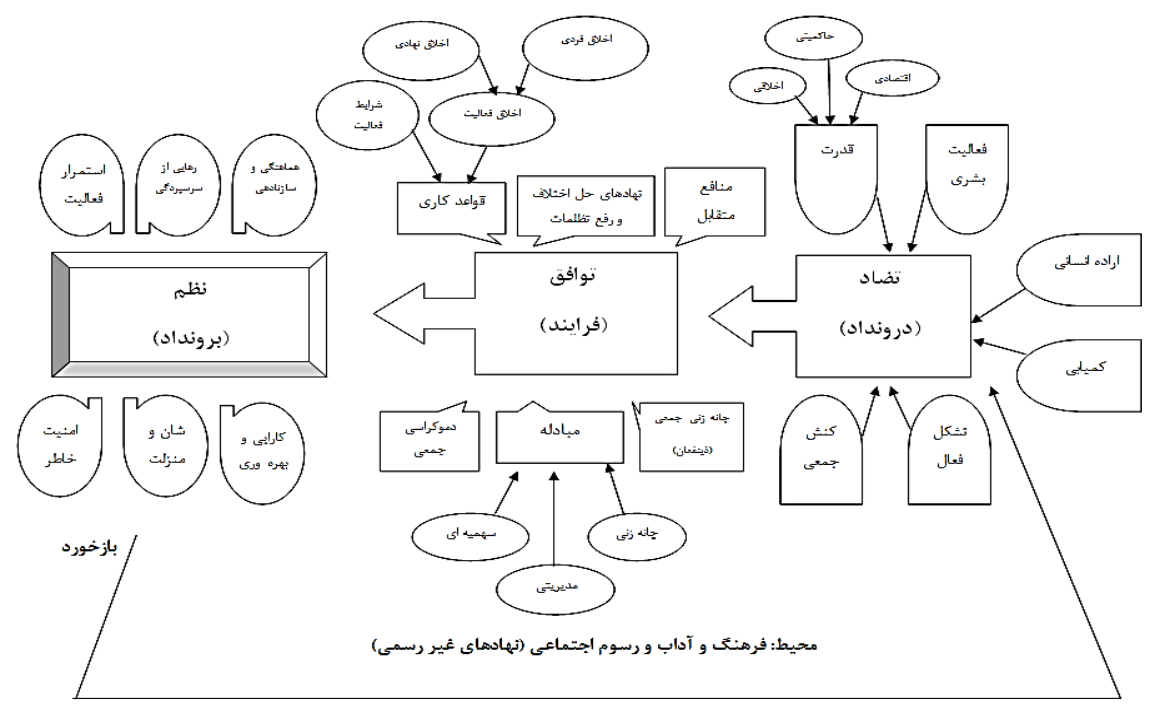

شكل Y: مدل مفهومى حكمرانى بر آمده از منظومه فكرى كامونز

بحث و نتيجه كيرى

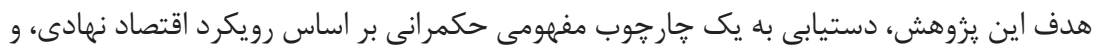

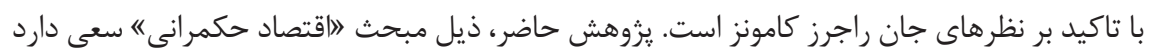

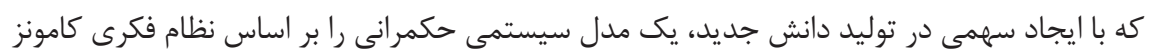

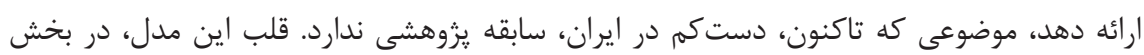

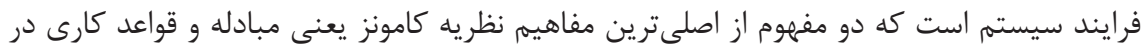

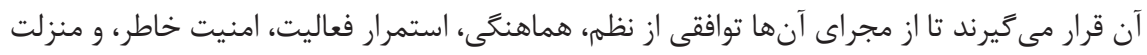

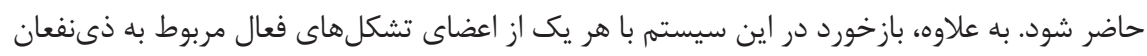

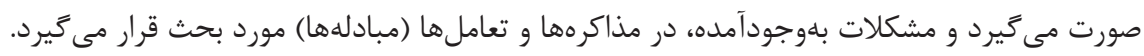

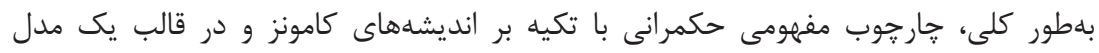

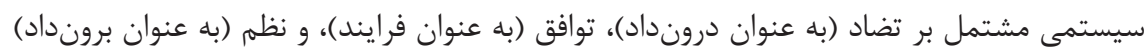

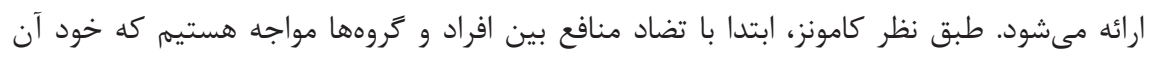

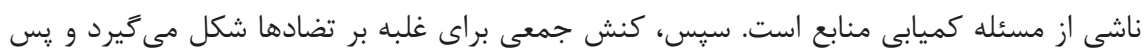


از آن مذاكره، مبادله، و جانهزنى جمعى بهوجود مى آيد و در نهايت، به قواعد كارى منجر مىشود تا

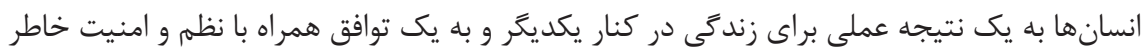

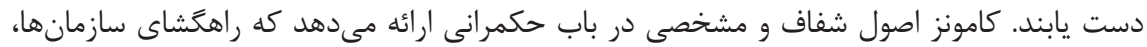
جوامع و كشورهاست. با بكارگيرى ايدههاى كامونز، در تصميمَيرىها و سياستخذارىها مىتوان كامهاى موثرى به سوى استقرار حكمرانى شايسته برداشت. وى راهكار اصلى سامانيابى امور جامعهد

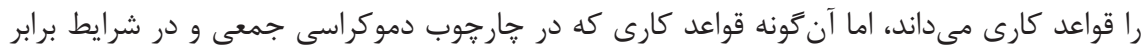

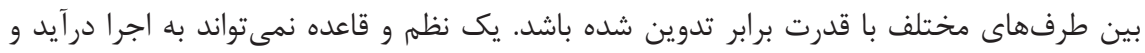

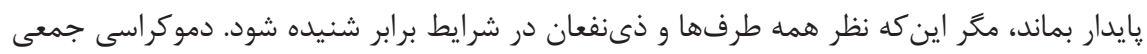
(دوسويه)، به عنوان يك روش حكمرانى دستيابى به اين هدف تسهيل رائ را مى كند.

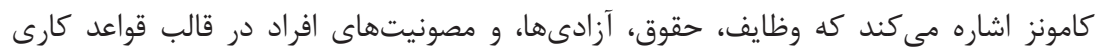
تعريف مىشود، همجنين تاكيد مى كند كه در تدوين قواعد كارى بايد برابرى وجود داشته باشد و

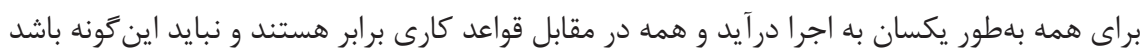

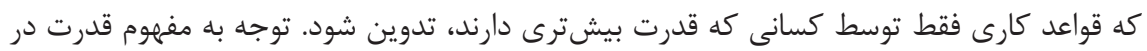

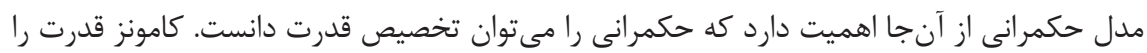

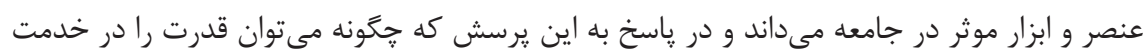

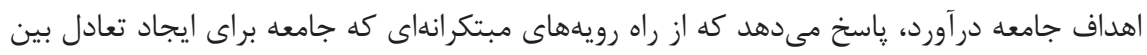
يك قدرت با قدرت ديخر يا نظارت يك قدرت بر قدرت ديخر وضع مى كند. در كذشته، فقط دولتها

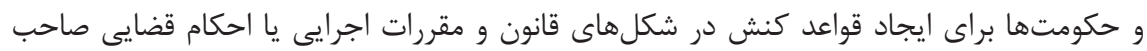

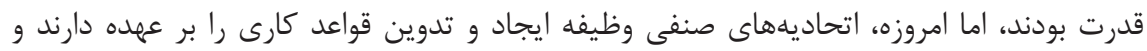

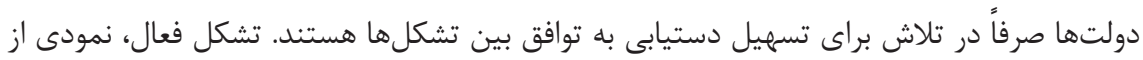
كنش جمعى است، منتها آن گونه كنش جمعى كه سازمان يافته و قاعدهمند باشد. طبق ديد كاه كامونز،

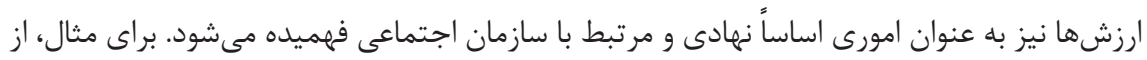

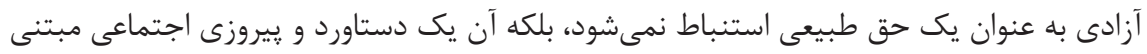
بر كنش جمعى است. در اقتصاد نئوكلاسيك، مبادله روى كالاها انجام مى گيرد، در حالى كه در نظر كامونز، مذاكره

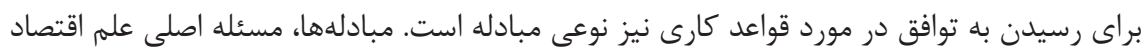

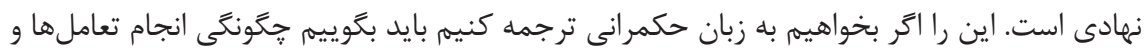


مبادلهها مسئله اصلى حكمرانى است. حكمرانى شكلدهنده روش مبادله و شيوه دستيابى به قواعد كارى مورد توافق است. كار حكمرانى، انتخاب و تنظيم انواع مبادله است، بلهطورى كه بيشترين بروندادهاى مثبت را به همراه داشته باشد. بر اساس اين، حكمرانى ابزارى براى برقرارى نظم است و

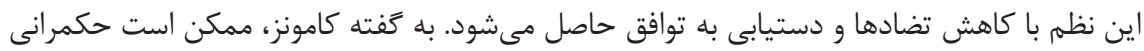

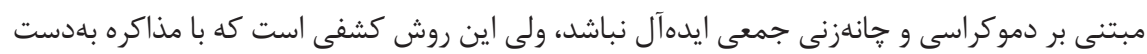

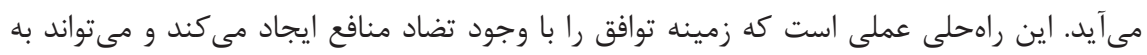

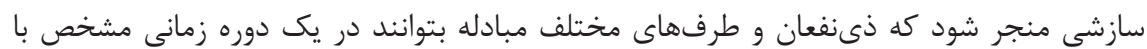
يكديگر كار كنند.

در پايان، بِيشنهادهاى اجرايى ارائه مىشود، مانند تقويت كنش جمعى با تشكلها و انجمنهاى

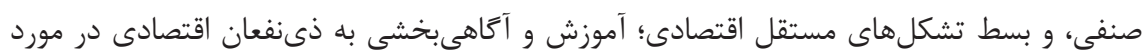
حقوق خود و كنجاندن اين حقوق در قواعد كارى؛ تعبيه سازوكارهاى بازخوردى قوى در تشكلهاى بهاى فعال اقتصادى به منظور فهم نظرهاى ذىنفعان؛ حضور تشكلهاى صنفى در جلسههاى تصميمَّيرى مربوط به امور ذىنفعان اقتصادى؛ نظارت نهادهاى بالاسرى بر تدوين قواعد كارى مورد توافق دوطرف در خار جوب دموكراسى جمعى؛ و نظرخواهى مستمر از ذىنفعان براى تدوين قوانين و مقررات مربوطه

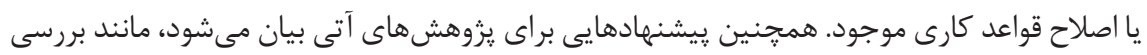

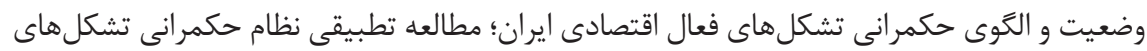
فعال در ايران و جهان؛ و آسيبشناسى تشكلهاى اقتصادى و ميزان حضور واقعى ذى نفعان در آنها.

امامقلى يور، سارا، و آسمانه، زهرا (ه9 (1). شاخص حكمرانى در اسلام و تاثير آن بر بروندادهاى سلامت در

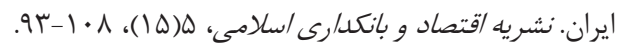

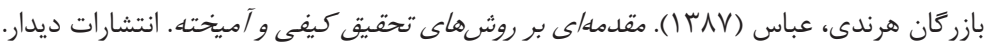

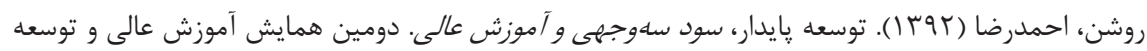
يايدار، دانشكده علوم اجتماعى دانشخاه تهران. 

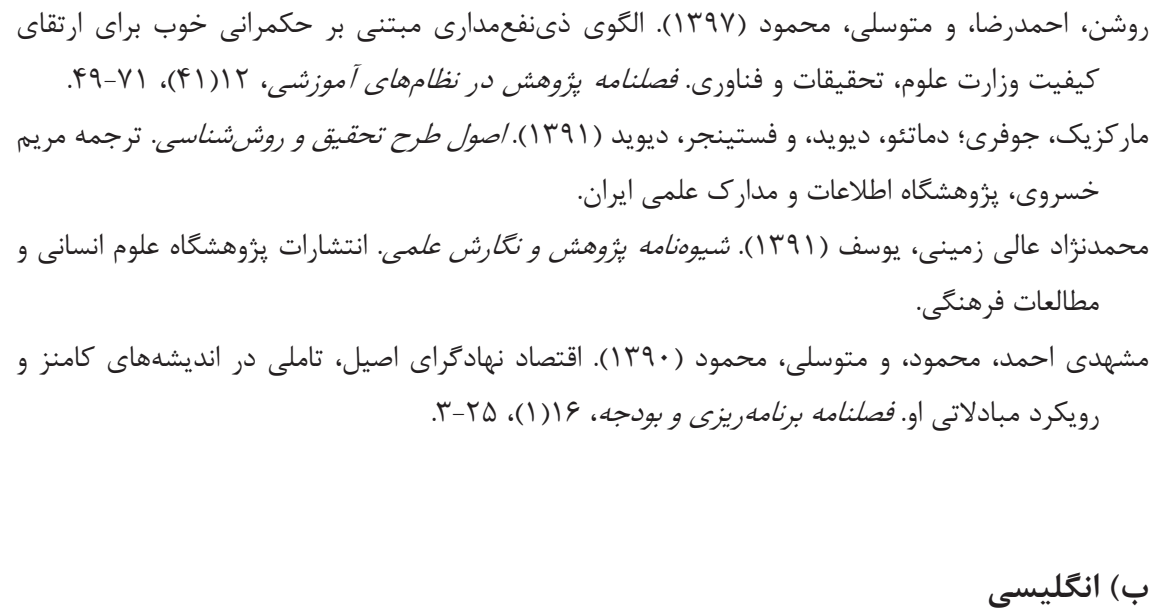

Adelstein, R. (1998). American Institutional Economics and the Legal System. The New Palgrave Dictionary of Economics and the Law, 1(1), 61-66.

Ball, S. J. (2010). New States, New Governance and New Education Policy. The Routledge International Handbook of the Sociology of Education, 155-165.

Commission on Global Governance. (1995) Our Global Neighbourhood. The Report of the Commission on Global Governance. Oxford \& New York: Oxford University Press.

Commons John, R. (1970). The Economics of Collective Action: The University of Wisconsin Press, Madison, Milwaukee.

Commons, J. R. (1924). Legal Foundations of Capitalism (Vol. 31): Transaction Publishers.

Commons, J. R. (1934). Institutional Economics: Its Place in Political Economy,-Reprinted 1990, Vol. I: New York: Macmillan.

Ebner, A. (2009). Governance, Institutions and Collective Action. International Encyclopedia of Public Policy Governance in a Global Age, 3(1), 218-231.

Hufty, M. (2011). Investigating Policy Processes: The Governance Analytical Framework (GAF). Research for Sustainable Development: Foundations, Experiences, and Perspectives, 403-424.

Lawson, C. (1999). Commons' Contribution to Political Economy'in Philip O'Hara (ed.) Encyclopedia of Political Economy: London: Routledge.

Marangos, J. (2007). John Rogers Commons on Power. International Journal of Political Economy, 35(4), 50-66.

McLaughlin, F. M. (2010). John Rogers Commons: Are His Insights Important in Teaching Modern Labor Economics? Paper Presented at the Lonergan Workshop.

Olson, M. (2009). The Logic of Collective Action: Public Goods and the Theory of Groups, Second Printing with a New Preface and Appendix (Vol. 124): Harvard University Press.

Parsons, K. H. (1970). Foreword to the 1970 Edition. Introduction, dans Commons JR [1950],[1970], p. vii-xvi, 9-18. 
Perlman, S. (1945). John Rogers Commons 1862-1945. The American Economic Review 35(4), 782-786

Powell, J. R., Short, C. J., Reed, M., \& Lewis, N. (2016). Commons: Governance of Shared Assets [PDF Version]: Countryside and Community Research Institute, University of Gloucestershire.

Ramstad, Y. (2001). John R. Commons's Reasonable Value and the Problem of Just Price. Journal of Economic Issues, 35(2), 253-277.

Rothstein, B. (2012). Good Governance. In: Levi-Faur D. (Ed.). The Oxford Handbook of Governance. Oxford University Press, 143-154.

Whalen, C. J. (1993). Saving Capitalism by Making It Good: The Monetary Economics of John R. Commons. Journal of Economic Issues, 27(4), 1155-1179.

Williamson, O. E. (2005). The Economics of Governance. American Economic Review, 95(2), 1-18 